\title{
Shear wave velocity by support vector machine based on geotechnical soil properties
}

\section{Shooshpasha ${ }^{1}$, A. Kordnaeij ${ }^{2}$, U. Dikmen ${ }^{3}$, H. MolaAbasi ${ }^{1}$, and I. Amir ${ }^{1}$}

${ }^{1}$ Faculty of Civil Engineering, Babol University of Technology, Babol, Iran

${ }^{2}$ Faculty of Engineering, Allameh Mohaddes Noori Institute of Higher Education, Noor, Mazandaran, Iran

${ }^{3}$ Faculty of Engineering, Ankara University, Ankara, Turkey

Received: 13 May 2013 - Accepted: 11 March 2014 - Published: 9 April 2014

Correspondence to: A. Kordnaeij (afshin_geotec@yahoo.com)

Published by Copernicus Publications on behalf of the European Geosciences Union.

Shear wave velocity

by support vector machine

I. Shooshpasha et al.

Title Page

Abstract

Introduction

Conclusions

References

Tables

Figures

14

4

$>$

Back

Close

Full Screen / Esc

Printer-friendly Version

Interactive Discussion 


\section{Abstract}

Shear wave velocity $\left(V_{S}\right)$ is a basic engineering property implemented in evaluating the soil shear modulus. In many instances it may be preferable to determine $V_{S}$ indirectly by common in-situ tests, such as the Standard Penetration Test (SPT). In this paper,

5 the relationship between $V_{S}$ and geotechnical soil parameters such as standard penetration test blow counts $\left(N_{160}\right)$, effective stress and fines content, as well as overburden stress ratio $\left(\sigma_{\mathrm{vo}} / \sigma_{\mathrm{vo}}^{\prime}\right)$, is investigated. A new mode based on support vector machine (SVM) approach is proposed to correlate geotechnical parameters and $V_{S}$, predicated on a total of 620 data sets, including field investigation records for the Kocaeli (Turkey, 1999) and Chi-Chi (Taiwan, 1999) earthquakes. This study addresses the question of whether Support Vector Machine (SVM) approach should be used to estimate $V_{S}$ based on the specified geotechnical variables, and assessing the influence of each variable on $V_{S}$. Results revealed that SVM, in comparison to previous statistical relations, provides an effective means of efficiently recognizing the patterns in data and accurately 15 predicting the $V_{S}$.

\section{Introduction}

Shear wave velocity $\left(V_{S}\right)$ is a principal geotechnical soil property in earthquake site response analysis; at small shear strain levels, is directly related to $V_{S}$. Owing to difficulties in soil sampling, and high costs of representative undisturbed specimens, insitu investigations (e.g. seismic measurements) in lieu of laboratory element testing, are preferred to determine $V_{S}$ directly. Using surface wave velocity measuring techniques, a shear wave velocity profile can be established without boring and penetration (Kramer, 1996). These nondestructive, non-intrusive features make $V_{S}$-based approach a potentially attractive alternative for characterizing liquefaction susceptibility in sandy
NHESSD

2, 2443-2461, 2014

\section{Shear wave velocity \\ by support vector machine}

I. Shooshpasha et al.

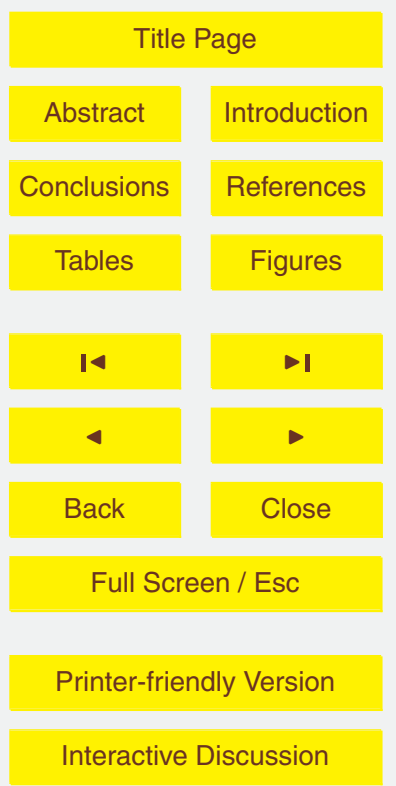


However, seismic in-situ tests are not always feasible; especially in urban areas, due to space constraints and noise level limits. Therefore, it is necessary to determine $V_{S}$ indirectly through methods such as the Standard Penetration Test (SPT) and Cone Penetration Test (CPT), which are commonly used for conventional geotechnical site 5 investigations.

In geotechnical engineering, different soil parameters are associated with the Standard Penetration Test blow counts $\left(N_{\mathrm{SPT}}\right)$. To the best of authors' knowledge, there is no established theoretical relationship between $N_{\mathrm{SPT}}$ and seismic soil properties (e.g. $V_{\mathrm{S}}$ ). Hence, their association, and evaluation of geotechnical properties, requires empirical correlations, statistical analysis and system identification techniques.

The interdependency of factors involved in such problems prevents the use of regression analysis and demands a more extensive and sophisticated method. The Support Vector Machine approach (SVM) can be used to model complex systems, where unknown relationships exist between variables, without having specific knowledge of process. In recent years, the use of mention approach has led to successful application of the SVM in geotechnical sciences (e.g. Goh, 2007; Oommenet et al., 2010).

This treatment aims to develop a SVM for the prediction of $V_{S}$, based on various soil parameters, such as $N_{160}$, depth and etc. Following the aims of the study, first reviews previous attempts in correlating $N_{\mathrm{SPT}}$ and $V_{\mathrm{S}}$, then a brief explanation of the case histories under consideration, and the phenomena of modeling with SVM are presented. Finally the developed SVM model is described and compared with previous studies.

\section{Background to previously proposed correlations}

The literature presents a portfolio of research regarding application of $N_{\mathrm{SPT}}$ for geotech-

nical characterization. Researchers have proposed correlations between $N_{\mathrm{SPT}}$ and $V_{\mathrm{S}}$ for different soil types, e.g. sand, silt and clay. Imai and Yoshimura (1975) studied 192 samples and proposed empirical relationships between seismic velocities and soil in-

\section{NHESSD}

2, 2443-2461, 2014

Shear wave velocity

by support vector machine

I. Shooshpasha et al.

Title Page

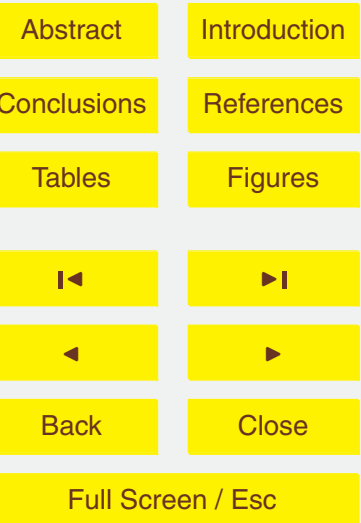

Printer-friendly Version

Interactive Discussion 
dex properties. Sykora and Stokoe (1983) asserted that geological age and soil type have little influence in predicting $V_{S}$. Jafari et al. (2002) presented a detailed historical review on statistical correlations between $N_{\mathrm{SPT}}$ and $V_{\mathrm{S}}$ for fine grained soils. Hasancebi and Ulusay (2007) reported correlations for sand and clay soil type. Ulugergerli and 5 Uyanık (2007) investigated statistical correlations using 327 specimens and defined empirically a range for $V_{S}$ values. Dikmen (2009) investigated $N_{\mathrm{SPT}}$ and presented a correlation for all soil types.

Others have developed correlating equations accounting for stress-corrected $V_{S}$, energy-corrected $N_{\text {SPT }}$ (e.g. Pitilakiset et al., 1999; Kikuet et al., 2001), energy- and 10 stress-corrected $N_{\mathrm{SPT}}$, depth (e.g. Tamura and Yamazaki, 2002) and fines content (e.g., Ohta and Goto, 1978). $V_{S}$ can also provide estimation of effective stress $\left(\sigma_{v}^{\prime}\right)$ for clayey soils as suggested by Mayne and Martin (1998). Mayne (2001) presented a relationship for the total unit weight $(\gamma)$ of saturated soils in terms of $V_{s}$ and depth $(Z)$. However, almost all the foregoing studies have focused on relationships between uncorrected ${ }_{15} N_{\mathrm{SPT}}$ and $V_{\mathrm{S}}$. Table 1 summarizes an inventory of prior researches and their proposed empirical correlations.

\section{Overview of database and case histories}

The destructive Kocaeli (Turkey) earthquake $\left(M_{\mathrm{W}}=7.4\right)$ occurred in 1999. The epicenter was located near the city of Izmit, and fault rupture was physically visible through 20 most of the seismically impacted area; from Karamürsel to Akyazı. In the vicinity of Adapazari, with peak ground accelerations recorded at approximately $0.4 \mathrm{~g}$, as much as $70 \%$ of buildings were subjected to large ground settlements, liquefaction or subsidence. Sea water inundation occurred at Değirmendere and Gölçük districts (Hanna et al., 2007). As illustrated in Fig. 1, the southern shores of Izmit Bay are covered by finer (more silty and clayey) northwards into the din A tor (more silty and clayey) northwards into the depths of lzmit Bay (Cetin et al., 2004). A total of 135 CPT profiles (19 were seismic CPTs) and 46 soil borings with multiple

\section{NHESSD}

2, 2443-2461, 2014

\section{Shear wave velocity \\ by support vector machine}

I. Shooshpasha et al.

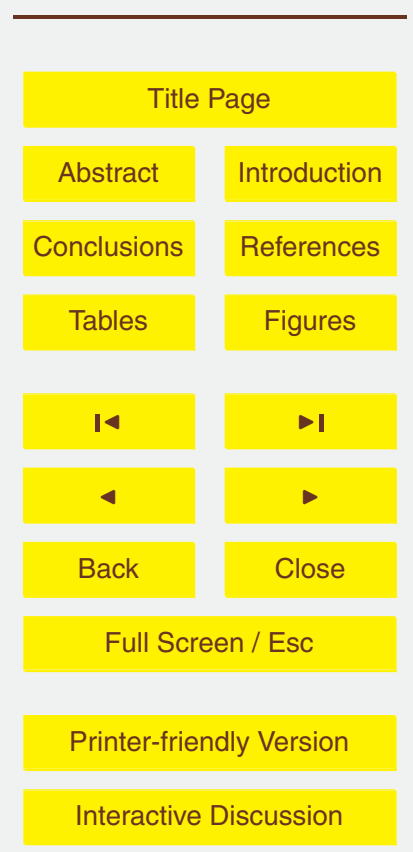


SPTs were completed in the city of Adapazari. Figure 2 shows soil profiles at the police station site, in the town of Gölçük located on the east shore of Izmit Bay. Accordingly, the soil liquefaction susceptibility is significant (Hanna et al., 2007).

The 1999 Chi-Chi (Taiwan) earthquake $\left(M_{\mathrm{W}}=7.6\right)$, triggered numerous major lique5 faction incidents in several coastal hydraulic fills and inland alluvial areas. The significant extent of ground failure, that is liquefaction, ground softening, and lateral spreading, were documented by researchers in several affected areas (Risk Management Solutions Inc, 2000). Further complementary information regarding the geotechnical and geological conditions of the sites are available in (Cetin et al., 2004; Chua et al., 10 2004).

Later site investigation programs were undertaken by National Center for Research on Earthquake Engineering (NCREE) (Scawthorn, 2000), resulting in a total of 92 CPT soundings (63 were seismic CPTs) and 98 soil borings with SPTs. Moreover, results of seismic CPTs and Spectral Analysis of Surface Waves (SASW) tests were used to interpret shear wave velocity data (Hanna et al., 2007).

Hanna et al, 2007 synthesized the results of both site investigation programs. Interpretations were predicated on SPT borings; 38 for the Kocaeli, and 25 for the Chi-Chi earthquake regions.

\section{Descriptive variables for the proposed models}

20 The field test results of the two mentioned earthquakes, i.e Chi-Chi and Kocaeli, are used in this investigation to develop a SVM model. The dataset, explained in Hanna et al. (2007), consists of 620 case records; 330 for Kocaeli and 290 for Chi-Chi. The database - a sample given in Table 2 - covers a wide range of soils and seismic parameters, including soil layer depth $(Z)$, corrected SPT blow number $\left(N_{160}\right)$, FC,

25 Fines Content $(\% \leq 75 \mu \mathrm{m})$, ground water table depth $\left(D_{\mathrm{w}}\right)$, total and effective overburden stresses $\left(\sigma_{\mathrm{vo}}, \sigma_{\mathrm{vo}}^{\prime}\right)$, stress ratio $\left(\sigma_{\mathrm{vo}} / \sigma_{\mathrm{vo}}^{\prime}\right)$ and $V_{\mathrm{S}}$. Further details regarding the measurement and interpretation of the foregoing parameters are available in Hanna
NHESSD

2, 2443-2461, 2014

Shear wave velocity

by support vector machine

I. Shooshpasha et al.

Title Page
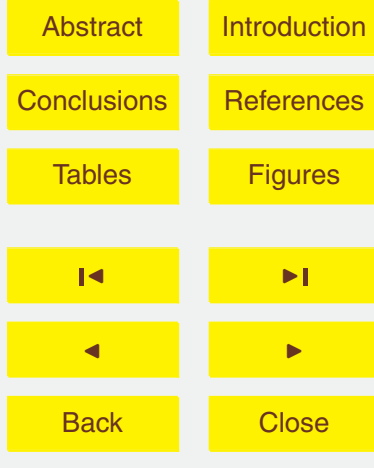

Full Screen / Esc

Printer-friendly Version

Interactive Discussion 
et al. (2007). Figure 3 illustrates the distribution of descriptive variable characteristics for all case histories.

\section{Principles of modeling using SVM}

The SVM has recently emerged as an elegant pattern recognition tool and a better al5 ternative to Artificial Neural Network (ANN) methods. The method has been advanced by Vapnik (1995) and is gaining popularity due to many attractive features. The formulation is based on Structural Risk Minimization (SRM) which has been shown to be superior to the Empirical Risk Minimization (ERM) used in conventional neural networks (Vapnik, 1995). This section of the paper serves an introduction to this relatively 10 new procedure. Details of this method can be found in Boser et al. (1992), Cortes and Vapnik (1995), Gualtieri et al. (1999) and Vapnik (1998).

\section{Modeling shear wave velocity using SVM}

By means of a SVM fitting, a model can be represented as a set of inputs in which different pairs of them are connected. In order to develop the evolved SVM, the database 15 is divided into two different sets, namely, training and testing. The training set consists of 500 inputs-output data pairs. The testing set, which consists of 120 inputs-output data unforeseen during the training process, is merely used for testing the trained SVM models. It should be noted that the training and testing sets are randomly selected from the data sets with approximately the same statistical properties. In order to illustrate the 20 model's predictive performance in comparison with observed data, 100 (from 50) data lines (inputs-output) are randomly selected from the training set. As it is shown in Fig. 4, predicted and measured values are properly close.

As presented in Table 3, the statistically assessed accuracy of the model is determined by $R^{2}$ (absolute fraction of variance), RMSE (root mean squared error), MSE
NHESSD

2, 2443-2461, 2014

Shear wave velocity

by support vector machine

I. Shooshpasha et al.

Title Page

\begin{tabular}{|c|c|}
\hline Abstract & Introduction \\
\hline Conclusions & References \\
\hline Tables & Figures \\
\hline $\mathbf{1}$ & \multicolumn{1}{|c|}{} \\
\hline & \\
\hline Back & Close \\
\hline Full Screen / Esc
\end{tabular}

Printer-friendly Version

Interactive Discussion 
(mean squared error), and MAD (mean absolute deviation) which are defined as follow:

$$
\begin{aligned}
& R^{2}=1-\left[\frac{\sum_{i=0}^{M}\left(Y_{i(\text { Model })}-Y_{i(\text { Actual })}\right)^{2}}{\sum_{i=1}^{M}\left(Y_{i(\text { Actual })}\right)^{2}}\right] \\
& \text { RMSE }=\left[\frac{\sum_{i=0}^{M}\left(Y_{i(\text { Model })}-Y_{i(\text { Actual })}\right)^{2}}{M}\right]^{1 / 2}
\end{aligned}
$$

MSE $=\frac{\sum_{i=0}^{M}\left(Y_{i(\text { Model })}-Y_{i(\text { Actual })}\right)^{2}}{M}$

$$
\mathrm{MAD}=\frac{\sum_{i=1}^{M}\left|Y_{i(\text { Model })}-Y_{i(\text { Actual })}\right|}{M}
$$

The ability of the SVM model in predicting unforeseen data is tested for the testing dataset. As it is illustrated in Fig. 5 results from the model agree well with measured values. Moreover, for $V_{S}$ in the range of 100 to $200 \mathrm{~m} \mathrm{~s}^{-1}$, the developed model is more accurate.

\section{Validation of predictive methods}

The accuracy of the proposed model in predicting $V_{S}$, is compared to correlations presented by Kiku et al. (2001), Hasancebi and Ulusay (2007) and Dikmen (2009) (cf.

NHESSD

2, 2443-2461, 2014

Shear wave velocity by support vector machine

I. Shooshpasha et al.

Title Page

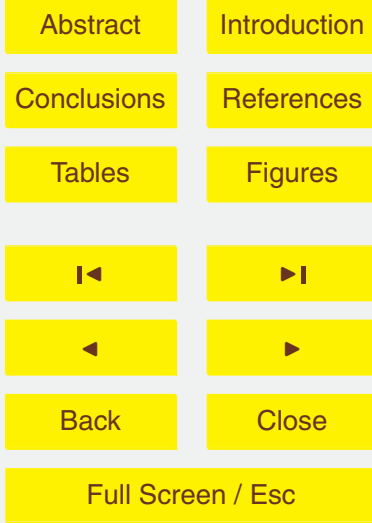

Printer-friendly Version

Interactive Discussion 
Table 1). A statistical comparison is performed for all the 620 cases which are initially used for the model development. Figure 6 illustrates the scattering of predicted (calculated by different methods) vs. observed $V_{\mathrm{S}}$.

It can be noted from the above diagrams that, the correlations of Kiku et al. (2001), 5 Hasancebi and Ulusay (2007) and Dikmen (2009), overestimate measured values, for observed $V_{S}<100\left(\mathrm{~ms}^{-1}\right)$. For $V_{S}>238\left(\mathrm{~ms}^{-1}\right)$, measured values of $V_{S}$ are higher than the predictions. Apparently, the disparity of $V_{S}$ prediction by the SVM approach is the least.

\section{Conclusions}

10 In this study, it has been attempted to deploy a system identification technique to develop the $V_{S}$ correlation with geotechnical soil properties, and assess their influence on $V_{S}$. The evolved Support Vector Machine (SVM) have been used to obtain a model for the prediction of $V_{S}$.

A SVM model was developed for $V_{\mathrm{S}}$ based on the depth of sampling, $N_{\mathrm{SPT}}$, total and 15 effective stress, fine content, and stress ratio $\left(\sigma_{\mathrm{vo}} / \sigma_{\mathrm{vo}}^{\prime}\right)$.

The validation and performance of the new model was assessed, and contrasted with previous statistical correlations. For all 620 case records, including $V_{S}$ and geotechnical soil properties, predicted and measured $V_{S}$ values were compared. The results manifested that predictions by the correlations of Kiku et al. (2001), Hasancebi and Ulusay 20 (2007) and Dikmen (2009) over estimate $V_{S}$ up to $V_{S}=100\left(\mathrm{~m} \mathrm{~s}^{-1}\right)$ and give lower $V_{S}$ values over $V_{S}=238\left(\mathrm{~m} \mathrm{~s}^{-1}\right)$. However, the proposed approach predicts $V_{S}$ with high accuracy and low variance.

In the field, a change in the soil layer may alter the $V_{S}$ values and this can be a source of error. Hence, predictive correlations are best suited for homogenous sites. Results obtained from this study and previous researches reveal that empirical correlations derived from a local dataset should not be implemented for different sites with significantly

\section{NHESSD}

2, 2443-2461, 2014

\section{Shear wave velocity \\ by support vector machine}

I. Shooshpasha et al.

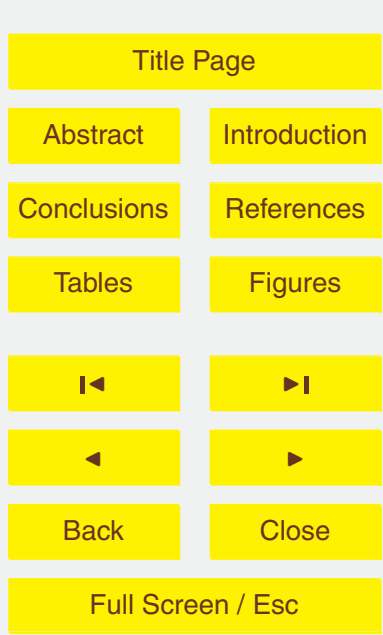

Printer-friendly Version Interactive Discussion 
varying features. Therefore, these proposed relationships should be used with caution in geotechnical engineering and should be checked against measured $V_{S}$.

\section{References}

Andrus, R. D., Piratheepanthan, P., Ellis, B. S., Zhang, J., and Juang, C. H.: Comparing liq5 uefaction evaluation methods sing penetration-VS relationships, Soil Dyn. Earthq. Eng., 24, 713-721, 2004.

Boser, B. E., Guyon, I. M., and Vapnik, V. N.: A training algorithm for optimal margin classifiers, in: 5th Annual ACM Workshop on COLT, edited by: Haussler, D., ACM Press, Pittsburgh, PA, 144-152, 1992.

Cetin, K. O., Youd, T. L., Seed, R. B., Bray, J. D., Stewart, J. P., Durgunoglu, H. T., Lettis, W., and Yilmaz, M. T.: Liquefaction-induced lateral spreading at Izmit Bay during the Kocaeli (Izmit)-Turkey earthquake, J. Geotech. Geoenviron. Eng., 130, 1 December 2004, ASCE, ISSN 1090-0241, 2004.

Chua, D. B., Stewarta, J. P., Leeb, S., Lind, P. S., Chud, B. L., Seed, R. B., Hsuf, S. C., Yug, M. S., and Wang, C. H.: Documentation of soil conditions at liquefaction and non-liquefaction sitesfrom 1999 Chi-Chi (Taiwan) earthquake, Soil Dyn. Earthq. Eng., 24, 647-657, 2004.

Dikmen, U.: Statistical correlations of shear wave velocity and penetration resistance for soils, J. Geophys. Eng., 6, 61-72, 2009.

Goh, A. T. C.: Support vector machines: their use in geotechnical engineering as illustrated using seismic liquefaction data, Comput. Geotech., 34, 410-421, 2007.

Hanna, A., Ural, D., and Saygili, G.: Neural network model for liquefaction potential in soil deposits using Turkey and Taiwan earthquake data, Soil Dyn. Earthq. Eng., 27, 521-540, 2007.

Gualtieri, J. A., Chettri, S. R., Cromp, R. F., and Johnson, L. F.: Support vector machine classifiers as applied to AVIRIS data, In the Summaries of the Eighth JPL Airbrone Earth Science Workshop, 1999.

Hasancebi, N. and Ulusay, R.: Empirical correlations between shear wave velocity and penetration resistance for ground shaking assessments, B. Eng. Geol. Environ., 66, 203-213, 2007.
NHESSD

2, 2443-2461, 2014

\section{Shear wave velocity \\ by support vector machine}

I. Shooshpasha et al.

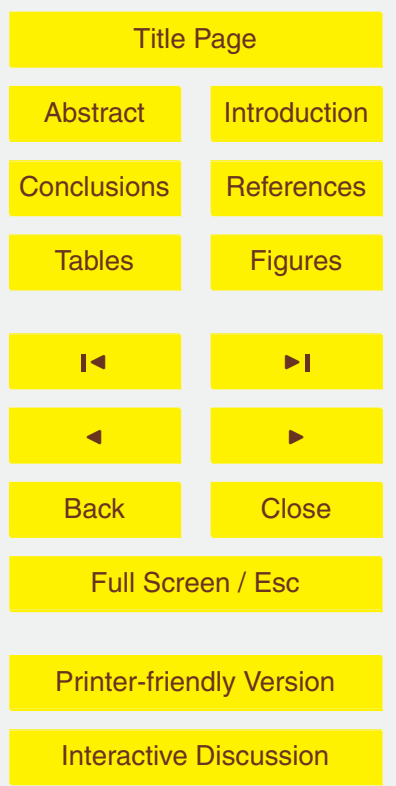


Imai, T. and Yoshimura, Y.: The relation of mechanical properties of soils to $\mathrm{P}$ and S-wave velocities for ground in Japan Technical Note OYO Corporation, 4th Japan Earthquake Engineering Symp, 89-96, 1975 (in Japanese).

Jafari, M. K., Shafiee, A., and Ramzkhah, A.: Dynamic properties of the fine grained soils in south of Tehran, J. Seismol. Earthq. Eng., 4, 25-35, 2002.

Kramer, S. L.: Geotechnical Earthquake Engineering, Prentice Hall publishing, Upper Saddle Hill River, NJ, 653 pp., 1996.

Kiku, H., Yoshida, N., Yasuda, S., Irisawa, T., Nakazawa, H., Shimizu, Y., Ansal, A., and Erkan, A.: In-situ penetration tests and soi profiling in Adapazarı, Turkey Proc. ICSMGE/TC4

10 Satellite Conf. on Lessons Learned from Recent Strong Earthquakes, 259-265, 2001.

Mayne, P. W.: Stress-strain-strength-flow parameters from enhanced in-situ tests, in: Proceedings of International Conference on In-Situ Measurement of Soil Properties and Case Histories (In-Situ 2001), Bali, Indonesia, 47-69, 2001.

Mayne, P. W. and Martin, G. K.: Commentary on Marchetti flat dilatometer correlations in soils, 15 ASTM Geotechnical Testing Journal, 21, 222-239, 1998.

Ohta, Y. and Goto, N.: Empirical shear wave velocity equations in terms of characteristic soil indexes, Earthq. Eng. Struct. D., 6, 167-87, 1978.

Oommen, T., Baise, L. G., and Vogel, R.: Validation and application of empirical liquefaction model, J. Geotech. Geoenviron., 136, 1618-1633, 2010.

20 Pitilakis, K., Raptakis, D., Lontzetidis, K. T., Vassilikou, T., and Jongmans, D.: Geotechnical and geophysical description of Euro-Seistests, using field and laboratory tests and moderate strong ground motions, J. Earthq. Eng., 3, 381-409, 1999.

Risk Management Solutions Inc: Event report, Chi-Chi, Taiwan earthquake, CA, USA, 2000.

Scawthorn, C.: Earthquakes of 1999, in: Euro Conference on Global Change and Catastrophe Risk Management: Earthquake Risks in Europe, Laxenburg, Austria, 2000.

Sykora, D. E. and Stokoe, K. H.: Correlations of in-situ measurements in sands of shear wave velocity, Soil Dyn. Earthq. Eng., 20, 125-36, 1983.

Tamura, I. and Yamazaki, F.: Estimation of S-wave velocity based on geological survey data for K-NET and Yokohama, J. Struct. Mech. Earthq. Eng., 1 , 237-248, 2002 (in Japanese).

30 Ulugergerli, U. E. and Uyanık, O.: Statistical correlations between seismic wave velocities and SPT blow counts and the relative density of soils, J. Test. Eval., 35, 1-5, 2007.

Vapnik, V. N.: The Nature of Statistical Learning Theory, Springer, New York, 1995.

Vapnik, V. N.: Statistical Learning Theory, Wiley, New York, 1998.
NHESSD

2, 2443-2461, 2014

Shear wave velocity

by support vector machine

I. Shooshpasha et al.

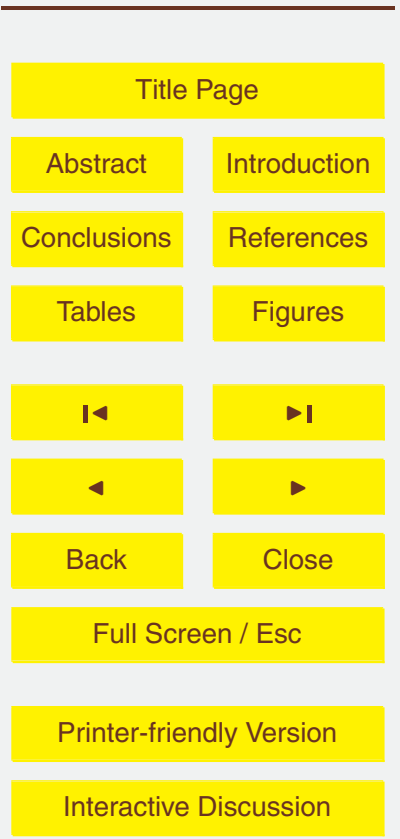




\section{NHESSD}

2, 2443-2461, 2014

\section{Shear wave velocity \\ by support vector machine}

Table 1. Inventory of proposed correlations between uncorrected $N_{\mathrm{SPT}}$ and $V_{\mathrm{S}}$ by previous researchers.

\begin{tabular}{ll}
\hline Ref. & Proposed relation for all soils \\
\hline Imai and Yoshimura (1975) & $V_{\mathrm{S}}=89.9 N^{0.341}$ \\
Ohta and Goto (1978) & $V_{\mathrm{S}}=85.35 N^{0.348}$ \\
Sykora and Stokoe (1983) & $V_{\mathrm{S}}=100.5 N^{0.29}$ \\
Jafari et al. (1997) & $V_{\mathrm{S}}=22 N^{0.85}$ \\
Kiku et al. (2001) & $V_{\mathrm{S}}=68.3 N^{0.292}$ \\
Jafari et al. (2002) & $V_{\mathrm{S}}=27 N^{0.73}$ (Clay type) \\
Hasancebi and Ulusay (2007) & $V_{\mathrm{S}}=90 N^{0.309}$ \\
Ulugergerli and Uyanık (2007) & $a-V_{\mathrm{S}}=23.29 \ln (N)+405.61$ \\
& $b-V_{\mathrm{S}}=52.9 e^{-0.011 N}$ \\
& $V_{\mathrm{S}}=58 N^{0.39}$ \\
\hline
\end{tabular}

I. Shooshpasha et al.

Title Page

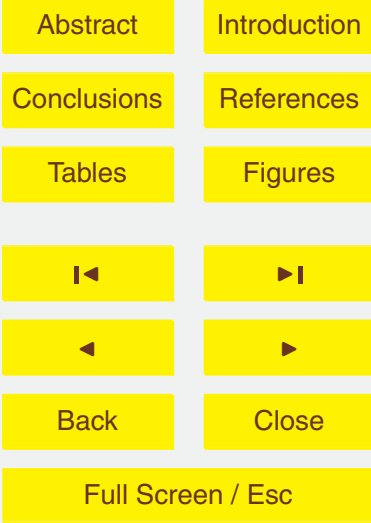

Printer-friendly Version 
Table 2. A sample of the database used in this paper extracted from Hanna et al. (2007).

\begin{tabular}{llllllll}
\hline$Z(\mathrm{~m})$ & $N_{160}$ & $\mathrm{FC}(\%)$ & $D_{\mathrm{w}}(\mathrm{m})$ & $\sigma_{\mathrm{vo}}(\mathrm{kPa})$ & $\sigma_{\mathrm{vo}}^{\prime}(\mathrm{kPa})$ & $\sigma_{\mathrm{vo}} / \sigma_{\mathrm{vo}}^{\prime}$ & $V_{\mathrm{S}}\left(\mathrm{ms}^{-1}\right)$ \\
\hline 3.3 & 6 & 83 & 0.74 & 59 & 33.4 & 1.77 & 170 \\
17.8 & 31 & 80 & 5 & 342.5 & 217 & 1.58 & 294 \\
2 & 6 & 56 & 0.4 & 36.1 & 20.1 & 1.80 & 110 \\
2.7 & 12 & 53 & 0.84 & 47.5 & 28.9 & 1.64 & 110 \\
18.2 & 18 & 5 & 0.5 & 378 & 204.4 & 1.85 & 262 \\
1.4 & 4 & 99 & 0.44 & 23.9 & 14.3 & 1.67 & 100 \\
9 & 6 & 98 & 1.7 & 168 & 96.4 & 1.74 & 200 \\
16.2 & 13 & 74 & 2.5 & 300.2 & 165.8 & 1.81 & 172 \\
6.8 & 23 & 14 & 1.03 & 136.7 & 80.1 & 1.71 & 151 \\
2.6 & 6 & 92 & 1.64 & 45.6 & 36 & 1.27 & 253 \\
7.9 & 40 & 11 & 1.5 & 138.8 & 74.8 & 1.86 & 150 \\
14.8 & 5 & 98 & 2.5 & 273.4 & 152.8 & 1.79 & 172 \\
13.2 & 30 & 20 & 3.2 & 263.2 & 165.1 & 1.59 & 179 \\
2.5 & 13 & 65 & 0.45 & 42.4 & 21.9 & 1.94 & 105 \\
2.8 & 4 & 99 & 0.71 & 48.8 & 27.9 & 1.75 & 121 \\
6.5 & 8 & 99 & 1.72 & 118.6 & 70.8 & 1.68 & 95 \\
9 & 48 & 5 & 0.77 & 167.3 & 85 & 1.97 & 250 \\
2.6 & 4 & 99 & 1.5 & 43.2 & 32.2 & 1.34 & 85 \\
7.7 & 39 & 11 & 2.6 & 133 & 82 & 1.62 & 150 \\
17.8 & 16 & 12 & 0.85 & 328.7 & 162.4 & 2.02 & 243 \\
4.1 & 25 & 71 & 1.9 & 70 & 48 & 1.46 & 306 \\
3.4 & 4 & 78 & 1.5 & 56.8 & 38.3 & 1.48 & 150 \\
4 & 7 & 83 & 0.5 & 69.7 & 34.7 & 2.01 & 150 \\
14.8 & 36 & 35 & 1.9 & 302.7 & 176.2 & 1.72 & 363 \\
5.5 & 24 & 97 & 1.3 & 99.7 & 57.7 & 1.73 & 155 \\
\hline & & & & & & & \\
\hline
\end{tabular}

NHESSD

2, 2443-2461, 2014

Shear wave velocity by support vector machine

I. Shooshpasha et al.

Title Page

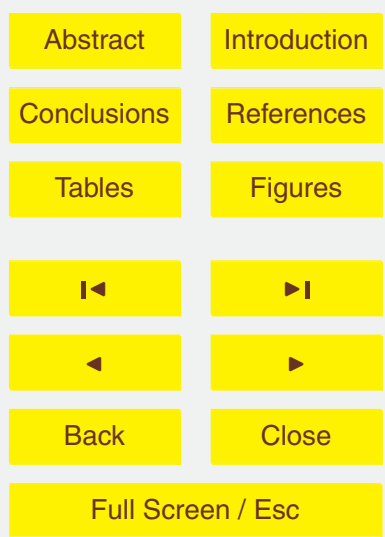

Printer-friendly Version

Interactive Discussion 


\section{NHESSD}

2, 2443-2461, 2014

\section{Shear wave velocity}

by support vector machine

I. Shooshpasha et al.

Title Page

Table 3. Statistical information for the SVM model for predicting $V_{S}$.

\begin{tabular}{lllll}
\hline Statistic & $R^{2}$ & MSE & MAD & RMSE \\
\hline Neural training & 0.95 & 1870 & 31 & 43 \\
Neural testing & 0.96 & 1718 & 25 & 41 \\
\hline
\end{tabular}




\section{NHESSD}

2, 2443-2461, 2014

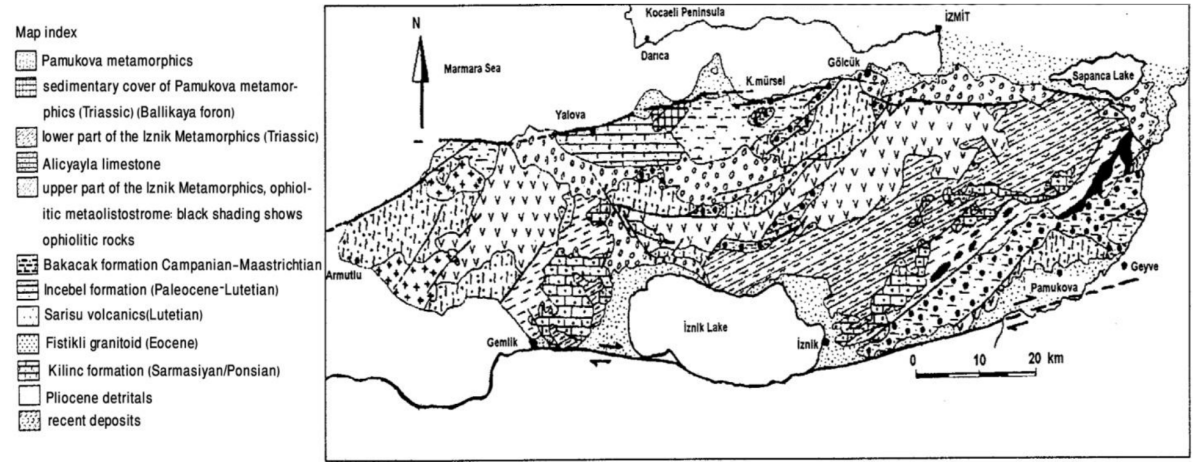

\section{Shear wave velocity}

by support vector machine

I. Shooshpasha et al.

Title Page

\begin{tabular}{|c|c|}
\hline Abstract & Introduction \\
\hline Conclusions & References \\
\hline Tables & Figures \\
\hline I4 & \\
\hline Back & \\
\hline Full Screen / Esc
\end{tabular}

Printer-friendly Version

Interactive Discussion 


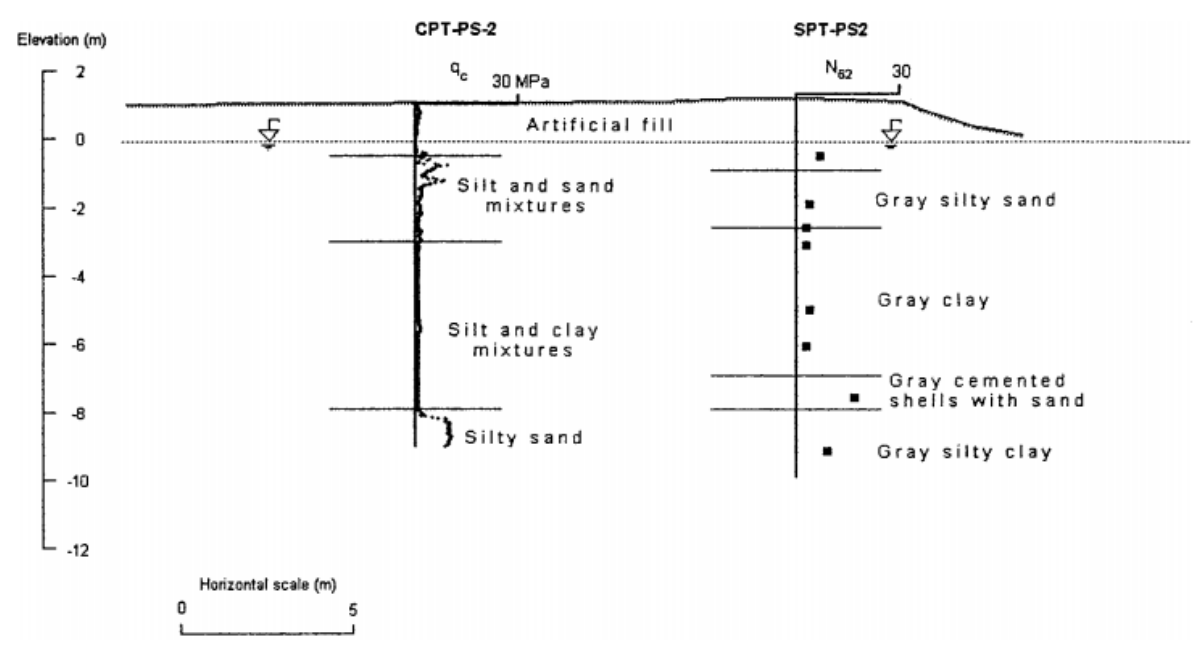

Fig. 2. Soil profile at the police station site located on the east shore of Izmit Bay, in the town of Gölçük (Cetin et al., 2004).

\section{NHESSD}

2, 2443-2461, 2014

\section{Shear wave velocity by support vector machine}

I. Shooshpasha et al.

Title Page

\begin{tabular}{|c|c|}
\hline Abstract & Introduction \\
\hline Conclusions & References \\
\hline Tables & Figures \\
\hline I4 & \\
\hline & \\
\hline Back & Close \\
\hline Full Screen / Esc \\
\hline
\end{tabular}

Printer-friendly Version

Interactive Discussion 
Depth of the soil layer $(\mathrm{m})$

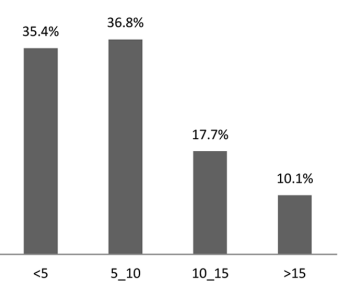

Fines content (\%)

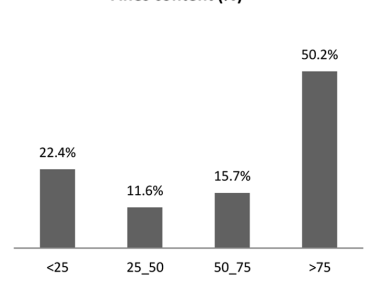

Total overburden stresses (kPa)

$41.2 \%$

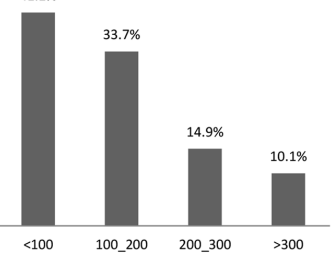

Total stress/Effective stress
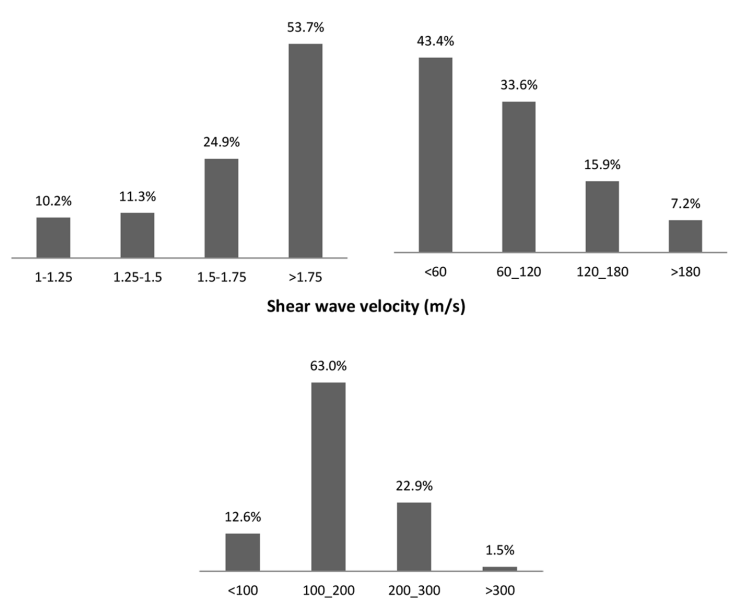

Fig. 3. Distribution of descriptive variable characteristics for all case histories.

\section{NHESSD}

2, 2443-2461, 2014

\section{Shear wave velocity}

by support vector machine

I. Shooshpasha et al.

Title Page

\begin{tabular}{|c|c|}
\hline Abstract & Introduction \\
\hline Conclusions & References \\
\hline Tables & Figures \\
\hline I4 & \\
\hline & \\
\hline Back & Close \\
\hline Full Screen / Esc \\
\hline
\end{tabular}

Printer-friendly Version

Interactive Discussion 


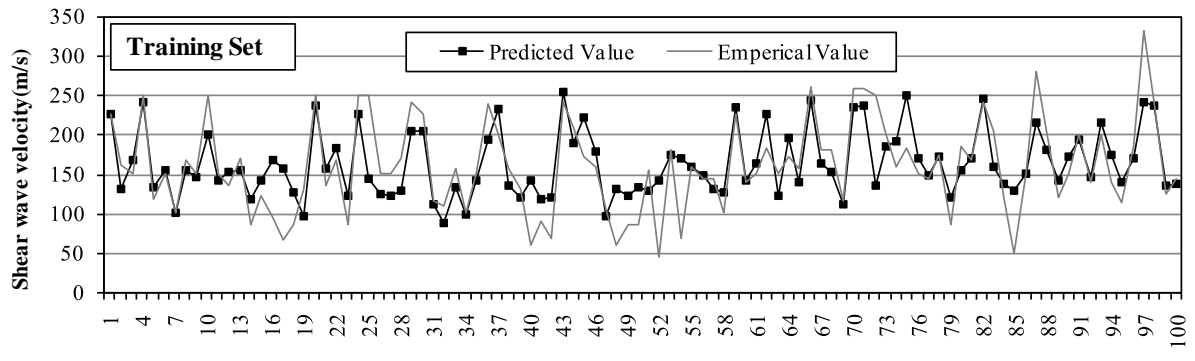

Dataset number

Fig. 4. SVM model predicted performance in comparison with observed data for the training set (100 inputs-output data).

\section{NHESSD}

2, 2443-2461, 2014

\section{Shear wave velocity \\ by support vector machine}

I. Shooshpasha et al.

Title Page

\begin{tabular}{|c|c|}
\hline Abstract & Introduction \\
\hline Conclusions & References \\
\hline Tables & Figures \\
\hline I & \\
\hline 4 & $-\mathbf{I}$ \\
\hline Back & Close \\
\hline Full Screen / Esc
\end{tabular}

Printer-friendly Version

Interactive Discussion 


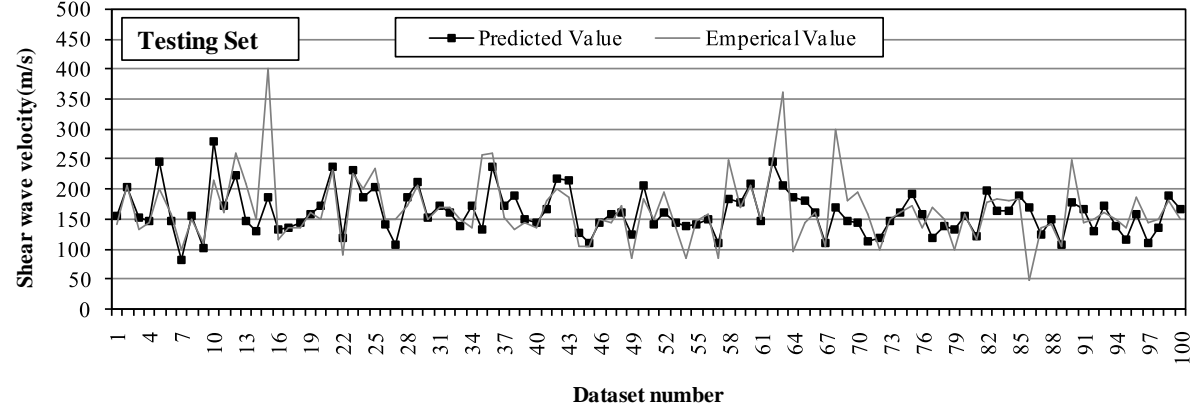

Fig. 5. SVM model predicted performance in comparison with observed data for the testing set.

\section{NHESSD}

2, 2443-2461, 2014

\section{Shear wave velocity \\ by support vector machine}

I. Shooshpasha et al.

Title Page

\begin{tabular}{|c|c|}
\hline Abstract & Introduction \\
\hline Conclusions & References \\
\hline Tables & Figures \\
\hline & \\
\hline Back & \\
\hline Full Screen / Esc \\
\hline Printer-friendly Version \\
\hline Interactive Discussion
\end{tabular}



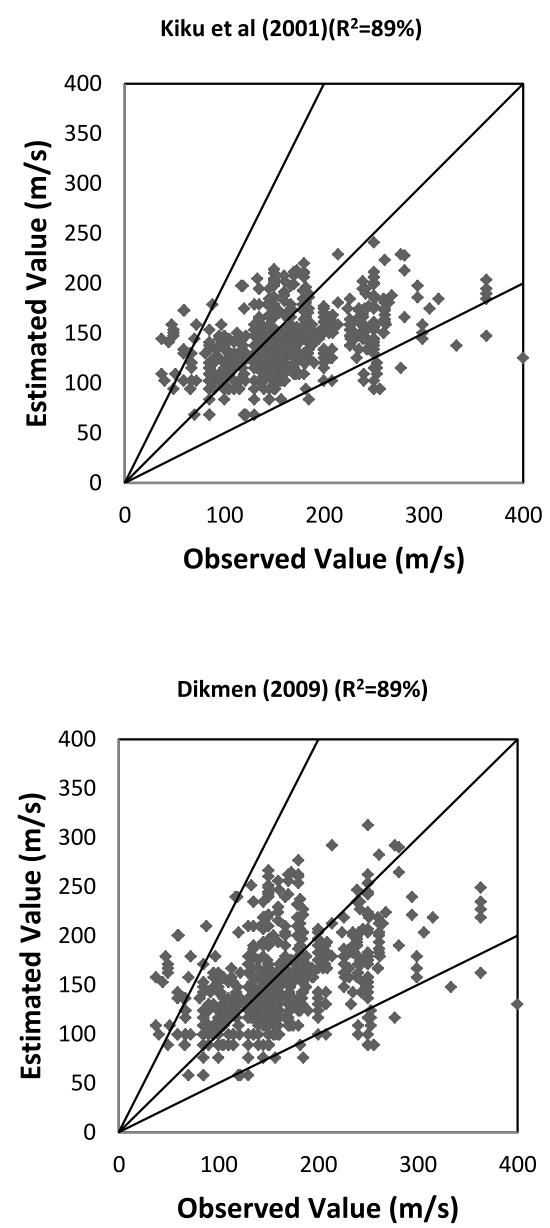

\section{Hasancebi and Ulusay $(2007)\left(R^{2}=86 \%\right)$}
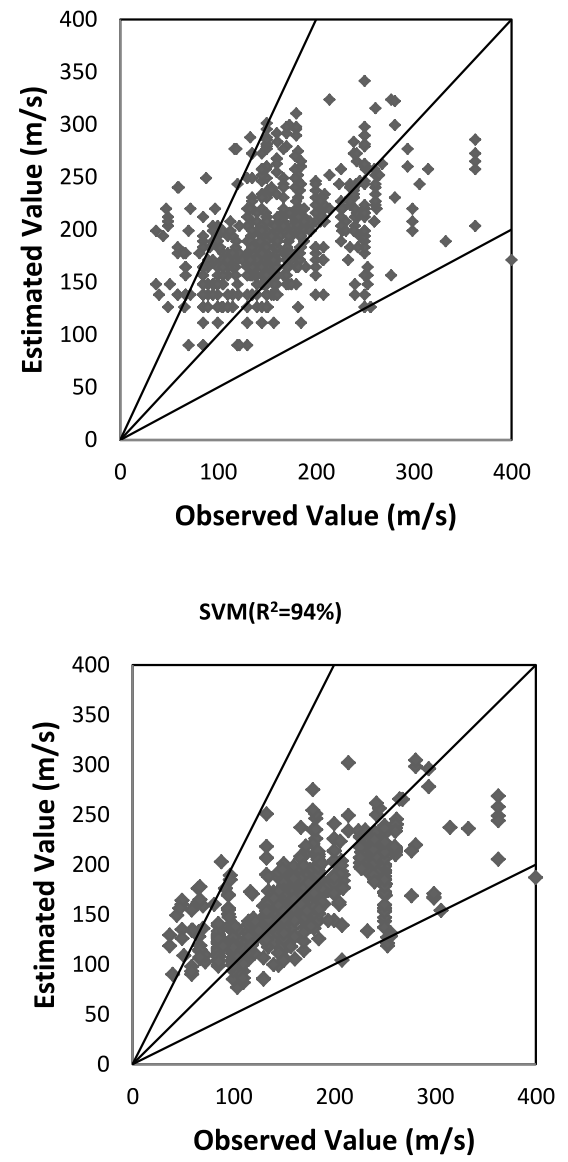

\section{NHESSD}

2, 2443-2461, 2014

\section{Shear wave velocity} by support vector machine

I. Shooshpasha et al.

\section{Title Page}

\begin{tabular}{|c|c|}
\hline Abstract & Introduction \\
\hline Conclusions & References \\
\hline Tables & Figures \\
\hline I4 & \\
\hline & \\
\hline Back & \\
\hline Full Screen / Esc \\
\hline Printer-friendly Version \\
\hline Interactive Discussion \\
\hline
\end{tabular}

Fig. 6. Estimated vs. measured Shear wave velocity $\left(\mathrm{ms}^{-1}\right)$ by different researchers correlations. 